\title{
Surface-layer sea ice assemblages in Antarctic pack ice during the austral spring: environmental conditions, primary production and community structure
}

\author{
David L. Garrison ${ }^{1}$, Kurt R. Buck ${ }^{2}$ \\ ${ }^{1}$ Institute of Marine Sciences, University of California, Santa Cruz, California 95064, USA \\ ${ }^{2}$ Monterey Bay Aquarium Research Institute, 160 Central Ave. Pacific Grove, California 93950, USA
}

\begin{abstract}
Favorable conditions for algal growth in sea ice develop during early spring as daylength and solar radiation increase. In the pack ice regions surrounding Antarctica, 'Surface-layer' and 'Internal' assemblages are the characteristic ice algal assemblages, whereas bottom-layer assemblages usually predominate in nearshore land-fast ice. Seasonal measurements of chlorophyll a have indicated little change in the algal biomas of internal assemblages, but very high concentrations (exceeding $400 \mu \mathrm{g} \mathrm{Chl} \mathrm{a}^{-1}$ ) have been reported for surface layer assemblages in late summer These observations suggest that most of the pack ice-associated production may depend on the formation and development of the surface-layer assemblages. In the austral spring (Nov), we measured chlorophyll a concentrations

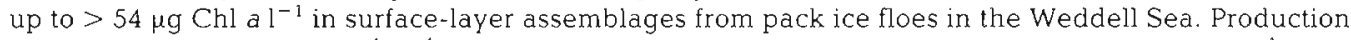
rates reached $>1.0 \mathrm{mg} \mathrm{Cl}^{-1} \mathrm{~d}^{-1}$ with growth rates of algae ranging from 0.2 to 0.6 doublings $\mathrm{d}^{-1}$. Two experiments in a variable light regime indicated the algal assemblages were adapted to high light conditions. Well-developed heterotrophic populations (e.g. flagellates, ciliates, micrometazoans) were also present with heterotrophic biomass averaging $26 \%$ (range 1 to $>93 \%$ ) of the total biomass among samples. Correlation analysis suggested shading by snow cover, and grazing possibly influenced growth and biomass accumulation. The observed growth rates are sufficient to account for the development of surface-layer assemblages found in spring into the very high concentrations reported in late austral summer. Calculations of algal biomass accumulation based on available nutrients, however, indicated that net nutrient transport from water into the ice assemblage would be necessary to reach such high densities. A pattern of high algal biomass along the edge ice floes, with biomass decreasing toward the floe center, suggest nutrient transport, but the role of light entering ice floes from the side and producing this distribution cannot be ruled out. Estimates of ingestion and respiration by heterotrophic members of the ice biota suggest that grazing could affect community development and succession. Field observations indicate the development of surface-layer assemblages is extremely patchy. It follows that accurate estimates of ice-assocciated production depend on a better understanding of their ecology.
\end{abstract}

\section{INTRODUCTION}

An assemblage comprised of bacteria, algae and protozoans occurs throughout the sea ice surrounding Antarctica (reviewed by Garrison 1991). The composition, distribution and abundance of organisms in sea ice varies from location to location, and several more or less distinct ice assemblages, or habitats, have been described (Horner et al. 1988, Garrison 1991). Although there are exceptions, it is generally reported that bottom-layer, under-ice platelet layer and algal strand assemblages are characteristic of the land-fast ice regions, whereas surface-layer and internal assemblages characterize the pack ice (e.g. Ackley et al. 1979, Garrison et al. 1986, Garrison 1991). Differing physical conditions in these 2 environments appear to explain the major patterns in the distributions of the ice biota (Garrison et al. 1983, Clarke \& Ackley 1984, and the previously cited references).

The amount of ice-based primary production is still poorly known. Production estimates from bottom-layer assemblages in coastal fast-ice regions based on the 
maximum seasonal biomass of ca 70 to $130 \mathrm{mg}$ Chl a $\mathrm{m}^{-2}$ have suggested net production of ca 3 to $5 \mathrm{~g} \mathrm{C} \mathrm{m}^{-2}$ $\mathrm{yr}^{-1}$ (Hoshiai 1981, Palmisano \& Sullivan 1983, Grossi et al. 1987. Watanabe \& Satoh 1987). Short-term ${ }^{14} \mathrm{C}$ $\mathrm{HCO}_{3}$ uptake measurements in these habitats, how ever, have indicated potential production rates as high as $41 \mathrm{~g} \mathrm{C} \mathrm{m}^{-2} \mathrm{yr}^{-1}$ (Grossi et al. 1987). These nearshore habitats comprise a relatively small proportion of the sea ice surrounding Antarctica.

There have been few production measurements from the more extensive pack ice regions. The most extensive algal populations in pack ice are those distributed throughout floes as internal assemblages (Ackley et al. 1979, Horner et al. 1988, Garrison \& Buck 1989a, Dieckmann et al. 1990). Primary production measurements on melted ice core samples from pack ice floes in the autumn and winter have averaged 18 and $77 \mathrm{mg} \mathrm{C}$ $m^{-3} d^{-1}$ respectively (Kottmeier \& Sullivan 1987, 1990). Lizotte \& Sullivan (1991) reported a wide range of chlorophyll a specific uptake rates among samples from pack ice. Actual in situ production rates (i. e. rates for non-melted samples), however, are still unknown. Based on chlorophyll a measurements, there is little evidence of significant seasonal growth of most internal assemblages. For example, chlorophyll a concentrations are usually $<10 \mathrm{mg} \mathrm{Chl} \mathrm{a} \mathrm{m}^{-2}$ in first-year pack-ice floes, and they show little indication of any seasonal maximum (Garrison \& Buck 1989a, Dieckmann et al. 1990). If maximum seasonal biomass is used as an indication of production - as has been done in coastal regions - the annual net production associated with internal assemblages could be $<0.2 \mathrm{gC} \mathrm{m}^{-2}$ (assuming a C:Chl a ratio of 50:1; see also Ackley et al. 1979). However, a few measurements in surface-layer assemblages associated with pack ice indicate both high production rates and an apparent seasonal maximum development of algal stocks. For example, Burkholder \& Mandelli (1965) reported production rates in surface layer assemblages reaching $0.2 \mathrm{gC} \mathrm{m}^{-2} \mathrm{~d}^{-1}$ (>1 $\mathrm{gC} \mathrm{m}^{-3} \mathrm{~h}^{-1}$ ) with chlorophyll concentrations reaching $407 \mu \mathrm{g} \mathrm{Chl} \mathrm{a}{ }^{-1}$ during late austral summer. Other studies from late summer also show chlorophyll a concentrations reaching $>400 \mu \mathrm{g} \mathrm{Chl} \mathrm{a} \mathrm{l}^{-1}$ (e.g. Meguro 1962, Kristiansen \& Syvertsen 1990). During autumn, Kottmeier \& Sullivan (1990) measured production rates of $0.2 \mathrm{gC} \mathrm{m}^{-3} \mathrm{~d}^{-1}$ in surface 'slush' assemblages with chlorophyll a concentrations of $17 \mu \mathrm{g} \mathrm{I}^{-1}$ and production $>2.0 \mathrm{gC} \mathrm{m}^{-3} \mathrm{~d}^{-1}$ in surface ponds where chlorophyll concentrations were $52 \mu \mathrm{gl}^{-1}$. Burkholder \& Mandelli's (1965) rates were extrapolated over a $100 \mathrm{~d}$ growing season to estimate a potential production of $19 \mathrm{gC} \mathrm{m}^{-2}$ by surface assemblages (Horner 1985). However, since there is little information about the spatial and temporal distribution of surface-layer assemblages, this estimate must be regarded as tentative. Because of the vast areas covered by pack ice, surface-layer assemblages have a high potential for contributing ice-based production to the Antarctic pelagic system.

We describe environment, primary productivity rates and community composition of surface-layer ice algal assemblages in the Weddell Sea during the austral spring. At the beginning of our study (early Nov), the daylight period had increased to $>15 \mathrm{~h}$. Shipboard observations indicated well-developed surface layer assemblages in some ice floes, but in many other floes a markedly discolored surface layer assemblage was not apparent. Thus, this study provides information on the early stages in the development of the surface-layer community.

\section{MATERIALS AND METHODS}

Samples were collected from pack-ice floes in the Weddell Sea during austral spring of 1983 (Fig. 1). To collect ice samples, snow was removed to expose underlying ice floe, and samples from the surface layer were collected by removing a short ice core (ca $20 \mathrm{~cm}$ ) and collecting accumulated brine that filled the core hole. In some floes ice-algal populations appeared as dense, slush-like mixtures of ice, algae and brine within a porous layer in the upper 10 to $30 \mathrm{~cm}$ of the ice floe. Because these samples contained mostly seawater or brine, it was not necessary to follow our usual procedure of melting samples in large volumes of filtered sea water to buffer osmotic changes resulting from ice melting (e.g. Garrison \& Buck 1986).

Aliquots of samples for microscopy were preserved with either Karnovsky's solution (Gold 1976) or Lugol's



Fig. 1 Stations in the Weddell/Scotia Sea where ice samples were collected during AMERIEZ 83. Ranges of sample numbers at single locations are shown. Ice covered regions are shaded. See Comiso \& Sullivan (1986) for more details about ice conditions during this cruise 
iodine. We examined some samples aboard ship using fluorescence microscopy to distinguish between autotrophic and heterotrophic flagellates. Freshly-collected samples were concentrated on $0.8 \mu \mathrm{m}$ Nuclepore filters, preserved with glutaraldehyde (ca $1 \%$ final concentration) and mounted with immersion oil and counted using an Olympus BH microscope (see Garrison \& Buck 1986, 1989a for more complete information about our methodology).

Preserved samples were stored in the dark and refrigerated during shipping and storage. Sample volumes of 10 to $100 \mathrm{ml}$ were settled and counted using an inverted microscope (Reid 1983). We measured cell dimensions to calculate cell volumes, and estimated cell carbon from published volume-to-carbon relationships (Beers \& Stewart 1970, Eppley et al. 1970, Putt \& Stoecker 1989). The potential biases in using these volume:carbon conversions are discussed in Garrison \& Buck (1989a).

Primary productivity by the ice algae was measured on 5 samples using the ${ }^{14} \mathrm{C}$ uptake method. Samples were inoculated with $20 \mu \mathrm{Ci}$ of $\mathrm{H}^{14} \mathrm{CO}_{3}^{-1}$ and incubated in polycarbonate bottles in a deckboard incubator at sea surface temperatures for $24 \mathrm{~h}$. Most samples were incubated in bottles covered with neutral density filters ( $30 \%$ transmission). In 2 experiments, a full range of filters $(1,5,15,30,50$ and $100 \%$ transmission) were used. At the end of the incubation samples were filtered through $0.8 \mu \mathrm{m}$ Millipore Filters. The filters were rinsed with ca $5 \mathrm{ml}$ of $0.01 \mathrm{~N} \mathrm{HCl}$ in sea water, placed in scintillation vials, and dried at $60^{\circ} \mathrm{C}$ for $24 \mathrm{~h}$. Ten $\mathrm{ml}$ of Omnifluor (New England Nuclear) was added to the vials and they were counted on a Beck- man LS-100 scintillation counter at sea. Quenching was corrected for by using the external standard ratio method (additional details about the productivity methods are given by Smith \& Nelson 1990)

Aliquots (100 to $500 \mathrm{ml})$ of surface-layer samples were filtered through Gelman glass fiber filters (GF/C), chlorophyll a was extracted in $90 \%$ acetone, and chlorophyll $a$ and phaeopigments were calculated from fluorescence measurements (Parsons et al. 1984). Dissolved nutrient concentrations $\left(\mathrm{NO}_{3}+\mathrm{NO}_{2}\right), \mathrm{PO}_{4}$ and silicic acid were measured with a 4 channel, continuous flow colorimeter using methods adapted from Atlas et al. (1971). Salinity was measured with a conductivity salinometer.

Continuous records of surface solar radiation (400 to $700 \mathrm{~nm}$ ) were made with a $4 \pi$ sensor (Biospherical Instruments). Total daily radiation was determined by integrating this record at $10 \mathrm{~min}$ intervals (Smith \& Nelson 1990). The AMERIEZ program was a 2-ship operation (Ainley \& Sullivan 1984); solar radiation measurements were taken on the second ship operating in open water at the ice edge. Because of the variability of cloud cover in the ice-edge region, radiation measurements are probably an indication of average conditions, but may not give precise local radiation data for individual daily productivity measurements on the ship operating within the pack ice where the productivity measurements were conducted. Sea surface and air temperatures were recorded in the ship's log at ca $6 \mathrm{~h}$ intervals throughout the cruise. Measurements of snow cover, floe thickness and size and other physical characteristics observed on ice floes were recorded as part of our field observations.

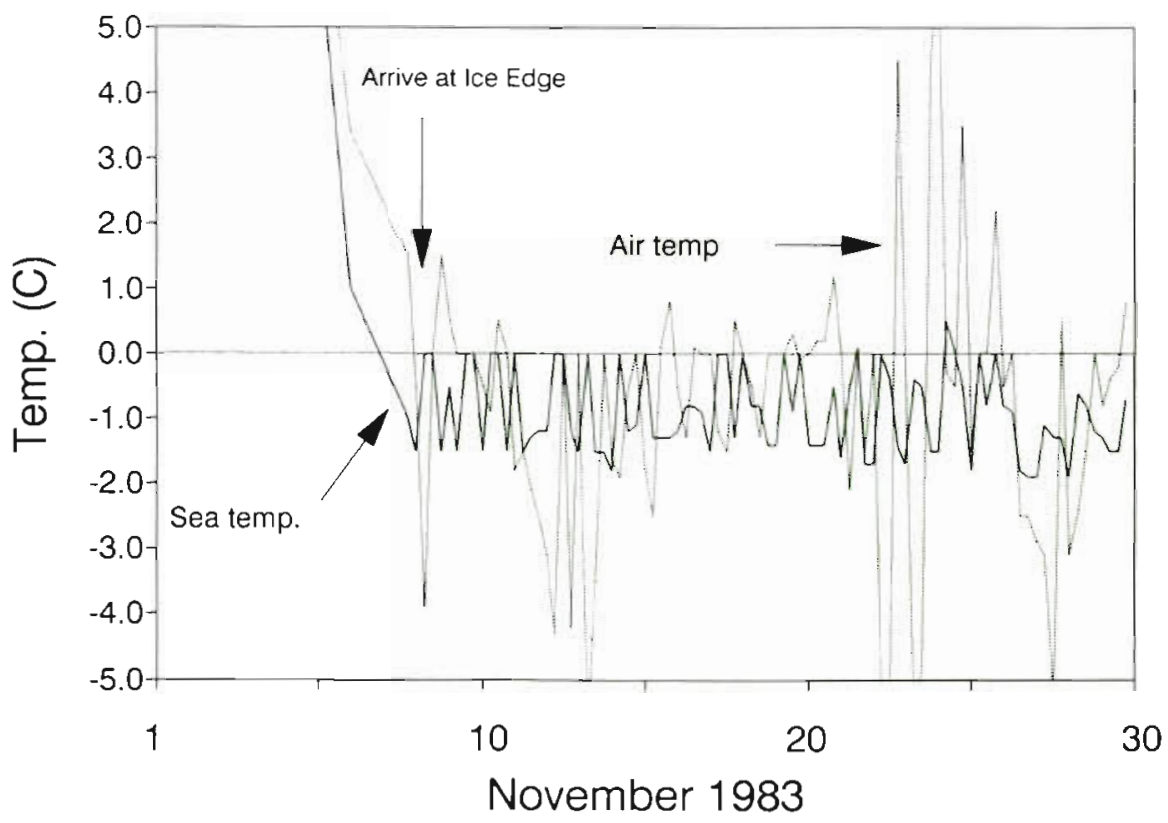

Fig. 2. Air temperature $\left({ }^{\circ} \mathrm{C}\right)$ and sea surface temperature $\left({ }^{\circ} \mathrm{C}\right)$ during the AMERIEZ 83 cruise 


\section{RESULTS}

\section{Environmental conditions}

Throughout the period we were within the pack ice, 8 to 30 November, air temperatures fluctuated between ca +6 and $-6{ }^{\circ} \mathrm{C}$ (Fig. 2). Episodes of marked freezing conditions were few and of short duration. Sea surface temperatures were often above the freezing point of sea water (Fig. 2). Temperatures in the surface layer of ice floes was not measured. During a winter cruise, we found that there was often a lag between atmospheric temperature and ice surface temperature, particularly

Table 1. (A) Summary of physical, chemical and biological paraneters measured in surface-layer ice assemblages. (B) For comparison with surface layer assemblage, ranges or mean \pm SD for parameters measured for first year sea ice (FYI), multiyear ice (MYI), and the water column (Water) are also given. Where voids were found in ice floes the range of the void space is given as measured from the surface of ice floes; where only 1 depth is given only the starting position of the voids or porous layer was recorded. (-) No voids recorded. Chlorophyll a values in FYI and MYI were determined on core samples and refer to internal assemblages. Integrated values in ice are for thickness of ice floes; the water column was integrated over the upper $100 \mathrm{~m}$. Chlorophyll data are from upper $100 \mathrm{~m}$ at ice-covered stations sampled by USCGC 'Westwind'. Nutrient and salinity samples are for surface waters at these same stations. Water-column data supplied by D. M. Nelson, L. I. Gordon and W. O. Smith, Jr. (see Nelson et al. 1987 for a more comprehensive report on these data)

\begin{tabular}{|c|c|c|c|c|c|c|c|c|c|c|c|}
\hline \multicolumn{12}{|c|}{ (A) Parameters measured in surface-layer ice assemblages } \\
\hline \multirow{2}{*}{ Sample } & \multirow{2}{*}{$\begin{array}{l}\text { Snow } \\
\text { depth } \\
(\mathrm{cm})\end{array}$} & \multirow{2}{*}{$\begin{array}{l}\text { Void } \\
\text { depth } \\
(\mathrm{cm})\end{array}$} & \multirow{2}{*}{$\begin{array}{l}\text { Floe } \\
\text { thickness } \\
(\mathrm{cm})\end{array}$} & \multirow{2}{*}{$\begin{array}{c}\text { Surface } \\
\text { area } \\
\left(\mathrm{m}^{2}\right)\end{array}$} & \multicolumn{2}{|c|}{ Chl a } & \multirow{2}{*}{$\begin{array}{l}\text { Phaeo } \\
\left(\mu g 1^{-1}\right)\end{array}$} & \multirow{2}{*}{$\begin{array}{l}\text { Salinity } \\
\qquad(\%)\end{array}$} & \multirow{2}{*}{\multicolumn{2}{|c|}{$\begin{array}{r}\mathrm{NO}_{3}+\mathrm{NO}_{2} \quad \mathrm{PO}_{4} \\
-\quad\left(\mu \mathrm{mol} \mathrm{l^{-1 }}\right)\end{array}$}} & \multirow{2}{*}{$\begin{array}{l}\text { Silicate } \\
- \\
-\end{array}$} \\
\hline & & & & & $\left(\mu \mathrm{gl}^{-1}\right)$ & $\left(\mathrm{mg} \mathrm{m}^{-2}\right)$ & & & & & \\
\hline 107 & & & & & 24.6 & & 51.1 & & & & \\
\hline 108 & & & & & 31.6 & & 41.6 & & & & \\
\hline 120 & 25 & $10-20$ & & & 41.6 & 4.2 & 46.6 & 22.0 & & & \\
\hline 121 & 25 & $10-20$ & & & 50.0 & 5.0 & 96.6 & 19.0 & 15.0 & & 45.6 \\
\hline 122 & 25 & $10-20$ & & & 54.0 & 5.4 & 100.7 & 21.0 & & & \\
\hline 154 & 30 & & 121 & 1000 & 0.9 & & 1.1 & 23.0 & & & \\
\hline 167 & 22 & & 109 & & 4.2 & & 1.6 & 21.0 & & & \\
\hline 168 & 22 & & 109 & & 1.8 & & 2.0 & 21.0 & & & \\
\hline 175 & 15 & $2-10$ & 125 & 750 & 5.4 & 0.4 & 3.9 & 21.0 & & & \\
\hline 176 & 15 & $2-10$ & 125 & 750 & 20.6 & 1.6 & 15.7 & & & & \\
\hline 177 & 15 & $2-10$ & 125 & 750 & 14.6 & 1.2 & 20.4 & & & & \\
\hline 178 & 15 & $2-10$ & 125 & 750 & 25.0 & 2.0 & 26.6 & 25.0 & 1.2 & 0.5 & 4.1 \\
\hline 179 & & & 125 & 750 & 9.7 & & 10.4 & & & & \\
\hline 180 & & & 125 & 750 & 1.8 & & 2.1 & & & & \\
\hline 182 & 30 & $10-12$ & 125 & 750 & 2.2 & & 1.8 & & & & \\
\hline 183 & 30 & $10-12$ & 125 & 750 & & & 0.0 & 21.0 & & & \\
\hline • 193 & 25 & $10+$ & 151 & 1400 & 1.8 & & 2.0 & 18.0 & 0.0 & 0.1 & 3.5 \\
\hline 194 & 32 & & 191 & & 1.5 & & 1.8 & 23.0 & 11.8 & 0.7 & 52.8 \\
\hline 207 & & $>30$ & 181 & 700 & 0.2 & & 0.3 & 28.0 & 2.6 & 0.4 & 18.4 \\
\hline 208 & 33 & $10+$ & 190 & 1000 & 1.8 & & 2.5 & 25.0 & 0.4 & 0.0 & 2.1 \\
\hline$• 209$ & 10 & $15+$ & 191 & & 23.6 & & 29.5 & 28.0 & 2.0 & 0.3 & 36.7 \\
\hline 219 & 10 & $20+$ & 171 & & 1.0 & & 1.0 & 27.0 & 18.4 & 1.2 & 64.2 \\
\hline$• 221$ & 20 & $12+$ & 165 & & 0.5 & & 0.4 & 20.0 & 2.0 & 0.1 & 21.1 \\
\hline$\cdot 254$ & 19 & $6+$ & 87 & 900 & 1.0 & & 1.7 & 26.0 & 4.2 & 0.3 & 32.5 \\
\hline 255 & 3 & - & 87 & 900 & 0.1 & & 0.2 & 18.0 & 0.3 & 0.0 & 19.6 \\
\hline • 269 & 18 & $18-25$ & 225 & 1500 & 1.4 & 0.1 & 2.8 & 29.0 & 14.9 & 0.9 & 62.8 \\
\hline 278 & 18 & $13-18$ & 225 & 1500 & 2.8 & 0.2 & 2.8 & 32.0 & 15.5 & 0.8 & 63.9 \\
\hline \multicolumn{12}{|c|}{ (B) Values measured in ice cores and underlying water column } \\
\hline & $\begin{array}{l}\text { Snow } \\
\text { depth } \\
(\mathrm{cm})\end{array}$ & & 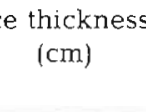 & & & & $\begin{array}{r}\text { Chemica } \\
{[\bar{X}}\end{array}$ & $\begin{array}{l}\text { measure } \\
\pm \mathrm{SD}(\mathrm{N})]\end{array}$ & nents & & \\
\hline FYI & $3-30$ & & $0.9-2.2$ & & $\begin{aligned} & 2.8 \\
\pm & 4.1(72)\end{aligned}$ & $\begin{array}{l}3.9 \\
+3.6(15)\end{array}$ & $\begin{array}{r}0.9 \\
\pm 1.3\end{array}$ & $\begin{array}{r}3.5 \\
\pm 1.5\end{array}$ & & & \\
\hline MYI & $4-18$ & & $>2.2$ & & $\begin{aligned} & 24.4 \\
\pm & 31.0(11)\end{aligned}$ & $\begin{array}{l}46.6 \\
\pm 6.1(2)\end{array}$ & $\begin{array}{r}1.5 \\
+2.2\end{array}$ & $\begin{array}{r}4.5 \\
+0.9\end{array}$ & & & \\
\hline Water & & & & & $\begin{aligned} & 0.2 \\
\pm & 0.01(18)\end{aligned}$ & $\begin{aligned} & 8.2 \\
\pm & 4.1(9)\end{aligned}$ & & $\begin{array}{r}34.08 \\
\pm 0.38\end{array}$ & $\begin{array}{r}27.41 \\
\pm 1.91\end{array}$ & $\begin{array}{r}1.82 \\
\pm 0.13\end{array}$ & $\begin{array}{c}88.57 \\
\pm 9.1\end{array}$ \\
\hline
\end{tabular}


when an insulating layer of snow was present (Garrison \& Buck 1989b). Thus, with only brief periods of subfreezing temperatures (Fig. 2), we expect that conditions in the ice were usually above freezing. The physical condition of the ice and the salinity of the brine (discussed below) support this contention. Integrated solar radiation showed considerable variation, varying from $<20$ to $>60 \mathrm{E} \mathrm{m}^{-2} \mathrm{~d}^{-1}$.

The ice floes sampled were mostly small $\left(<1000 \mathrm{~m}^{2}\right)$ first-year sea ice ranging from 0.9 to $1.9 \mathrm{~m}$ in thickness; one floe (> $2.2 \mathrm{~m}$ ) was probably a multi-year floe (Table 1). The snow ranged from 2 to $>30 \mathrm{~cm}$ and was variable both on and between ice floes in the same region. Most floes had voids or a porous layer 2 to $30 \mathrm{~cm}$ below the surface of hard ice that usually coincided with the freeboard level of the ice floes

\section{Chemical parameters}

Chlorophyll a concentrations in the surface layer assemblages ranged from 0.1 to $54 \mu \mathrm{g} \mathrm{Chl} \alpha^{-1}$ (Table 1 ). These showed considerable variation both among and between ice floes. One apparent pattern was high concentrations of chlorophyll a (e.g. ca $25 \mu \mathrm{g} \mathrm{Chl} \mathrm{a}^{-1}$ ) at the margin of floes decreasing to $<2.0 \mu \mathrm{g} \mathrm{Chl} \mathrm{a}^{-1}$ within $5 \mathrm{~m}$ of the floe edge. Although this was measured on only a single floe, it was evident from visual observations of several other floes. Chlorophyll a concentrations in well-developed surface layer assemblages were considerably higher (e.g. 30 to $50 \mu \mathrm{g} \mathrm{Chl} \mathrm{a}{ }^{-1}$ ) than those measured in internal assemblages (i. e. ice-core samples from deeper in the floes where Chl a averaged $<3.0 \mu \mathrm{g}$ $1^{-1}$; Table 1). The single multi-year floe was an exception to this pattern with chlorophyll concentrations in internal assemblages as high as those in the surface layer assemblages.

Salinities of the brine removed from the surface layer ranged from 18 to $32 \%$ (Table 1 ). This salinity range

Table 2. ${ }^{14} \mathrm{CHCO}_{3}$ uptake rates measured in surface layer assemblages at $30 \%$ surface solar radiation over $24 \mathrm{~h}$ incubation. $\mathrm{P} / \mathrm{C}=$ assimilation ratio $\left(\right.$ production $\left.\mathrm{h}^{-2}\right)\left(\mathrm{Chl} \text { a } \mathrm{l}^{-1}\right)^{-1}$. Growth rates $\mu$ (doublings $\mathrm{d}^{-1}$ ) were calculated from the expression: $\mu=\operatorname{Ln}\left(C_{t} / C_{0}\right) \operatorname{Ln}(2)^{-1}$, where $C_{0}$ was determined by microscopy analysis; $\mathrm{C}_{\mathrm{t}}=\mathrm{C}_{0}+\left(24 \mathrm{~h}{ }^{14} \mathrm{C}\right.$ uptake rate $)$

\begin{tabular}{|c|c|c|c|c|c|c|}
\hline Sample & $\begin{array}{l}\text { Snow } \\
(\mathrm{cm})\end{array}$ & $\begin{array}{c}\text { Chl } a \\
\left(\mu \mathrm{gl}^{-1}\right)\end{array}$ & $\begin{array}{l}\text { Produc } \\
\text { mg C } \\
\left(\mathrm{m}^{-3}\right)\end{array}$ & $\begin{array}{l}\text { tivity } \\
\mathrm{d}^{-1} \\
\left(\mathrm{~m}^{-2}\right)\end{array}$ & $\mathrm{P} / \mathrm{C}$ & $\begin{array}{c}\mu \\
\left(\mathrm{dbl} \mathrm{d}^{-1}\right)\end{array}$ \\
\hline 193 & 25 & 1.8 & 18.7 & 1,9 & 0.4 & 0.35 \\
\hline 209 & 10 & 23.6 & 1135.9 & 113.6 & 2.0 & 0.56 \\
\hline 221 & 20 & 0.5 & 7.0 & 0.7 & 0.6 & 0.18 \\
\hline 254 & 19 & 1.0 & 12.5 & 1.9 & 0.5 & 0.22 \\
\hline 269 & 10 & 1.4 & 43.2 & 4.3 & 1.3 & 0.30 \\
\hline
\end{tabular}

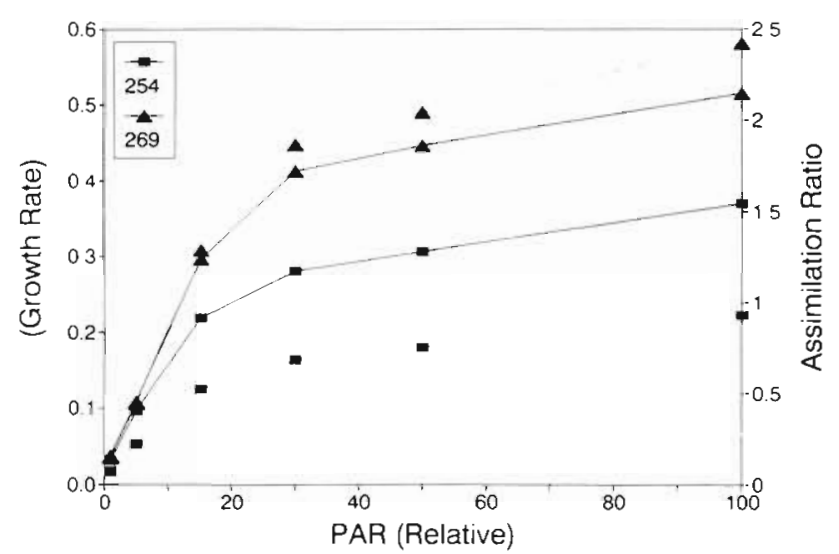

Fig. 3. Growth rate $\mu$ (doublings $d^{-1}$ ) (inner 2 lines) and assimilation ratio ( $\mu \mathrm{gCl}^{-1}\left[\mu \mathrm{gChl}_{\mathrm{a}}\right]^{-1} \mathrm{~h}^{-1}$ ) (upper and lower lines) of surface-layer assemblages determined at 6 light levels. The peak and $24 \mathrm{~h}$ average light levels experienced by samples in the $100 \%$ transmission sample would be 830,177 and 1290 , $258 \mu \mathrm{E} \mathrm{m}^{-2} \mathrm{~s}^{-1}$ for Samples 254 and 269 , respectively. Growth rates were calculated using $\mathrm{C}: \mathrm{Chl}$ a ratios of 76 and 189 for Samples 254 and 269, respectively. Autotrophic carbon was determined by microscopy

would be consistent with a freezing point of -1.1 to $-1.7^{\circ} \mathrm{C}$, and this was within the range of sea-surface temperatures measured during the study area (Fig. 2). However, there was some slush ice present in the samples, so some dilution may have taken place before salinity was measured. Nutrient concentrations from ice varied from those measured in the surrounding surface seawater water (Table 1).

\section{Production and growth rates}

Primary production rates varied considerably among the samples (Table 2) with the highest rates reaching $>1 \mathrm{gC} \mathrm{m}^{-3} \mathrm{~d}^{-1}\left(0.1 \mathrm{gC} \mathrm{m}^{-2} \mathrm{~d}^{-1}\right.$ integrated over the thickness of the surface-layer assemblage). The range of growth rates for samples incubated at $30 \%$ incident solar radiation was 0.18 to 0.56 doublings $\mathrm{d}^{-1}$. The 2 experiments incubated under a range of 6 light levels (Fig. 3) showed the highest growth rates at full light intensities.

\section{Community composition}

Autotrophic biomass, as estimated by microscopy, ranged from $<6 \mu \mathrm{g}$ to $>3 \mathrm{mgC} \mathrm{l}^{-1}$ (Fig. 4a). Carbon: chlorophyll a ratios based on this analysis ranged from 14 to 270 and averaged 106. Diatoms dominated the biomass in most samples (Fig. 4). However, autotrophic dinoflagellates and the prymnesiophyte Phaeocystis (i. e. autotrophic flagellates) were occasionally dominant. The autotrophic ciliate Myrionecta rubra was pre- 


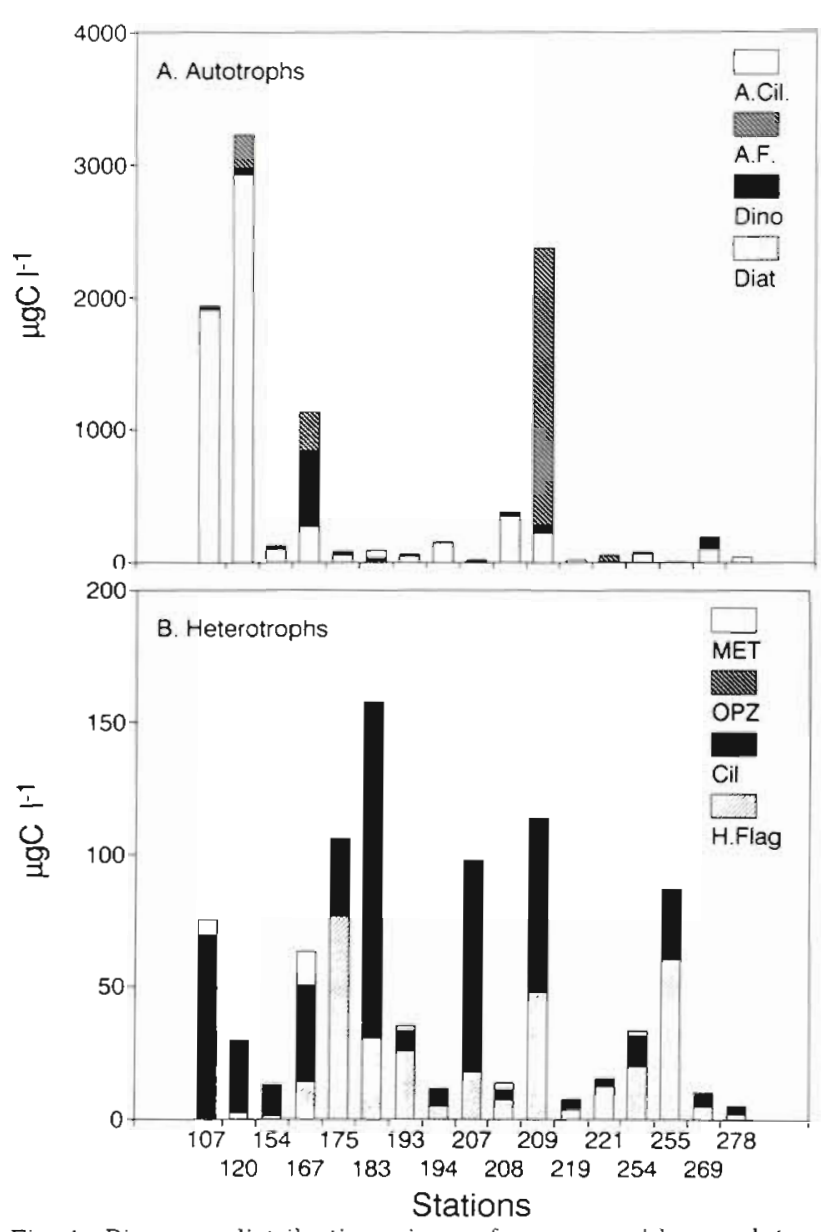

Fig. 4. Biomass distributions in surface assemblages determined by microscopy. (A) Autotrophs: Diat, diatoms; Dino, autotrophic dinoflagellates; A.F., autotrophic flagellates; A.Cil, the ciliate Myrionecta rubra. (B) Heterotrophs: H.Flag, heterotrophic flagellates; Cil, ciliates; OPZ, other Protozoa; MET, copepod nauplii sent in most samples, but contributed little to the total autotrophic biomass. Heterotrophic biomass ranged from 3 to $160 \mu \mathrm{g} \mathrm{C} \mathrm{l}^{-1}$ (Fig. 4b). The contribution of heterotrophs to the total ice biota biomass ranged from ca 1 to $>90 \%$ among samples. Average abundances, biomasses and carbon cell ${ }^{-1}$ determined for various major groups of heterotrophic organisms in surface layer assemblages are shown in Table 3.

\section{DISCUSSION}

Many authors (e.g. Ackley et ai. 1979, Garrison et al. 1986, Kottmeier \& Sullivan 1987, 1990, Garrison \& Buck 1989a, Lizotte \& Sullivan 1991) have recognized that the seasonal pack ice surrounding Antarctica comprises an extensive habitat and have speculated that the ice-associated algal assemblage may contribute a significant amount to regional primary production. Recent studies by Kottmeier \& Sullivan (1987, 1990) and Lizotte \& Sullivan (1991) have reported a wide range of production rates from a variety of habitats in pack ice during autumn and winter. Production versus light (P vs I) measurements by Lizotte \& Sullivan (1991) show that the algae associated with pack ice usually have a high photosynthetic capacity with photosynthetic characteristics similar to those of phytoplankton and differing markedly from those of low-light, near-shore fast-ice algal assemblages. There are, however, no convincing areal estimates of production in the pack ice regions, because information about the seasonal occurrence and activity of pack-ice algal assemblages is still very sparse. One can predict that much of the production should occur during spring and summer in

Table 3. Summary of abundance, biomass and body mass (carbon cell ${ }^{-1}$ ) of heterotrophic organisms in the surface layer assemblage. $\mathrm{N}$ : number of samples in which groups were found out of 16 samples. Mean \pm standard deviations are shown.

\begin{tabular}{|c|c|c|c|c|}
\hline & $\mathrm{N}$ & $\begin{array}{c}\text { Abundance } \\
\left(\# l^{-1}\right)\end{array}$ & $\begin{array}{l}\text { Biomass } \\
\left(\mu g \mathrm{Cl}^{-1}\right)\end{array}$ & $\begin{array}{c}\text { Carbon } \\
\left(\mathrm{pgC} \text { cell }^{-1}\right)\end{array}$ \\
\hline \multicolumn{5}{|l|}{ Heterotrophic flagellates } \\
\hline Heterotrophic nan. ${ }^{\beth}$ & 16 & $9.1 \pm 9.4 \times 10^{4}$ & $1.1 \pm 1.7$ & $15 \pm 10$ \\
\hline Cryothecomonas armigera & 15 & $0.9 \pm 1.3 \times 10^{5}$ & $13.1 \pm 22.1$ & $144 \pm 65$ \\
\hline Heterotrophic dinos. ${ }^{.3}$ & 14 & $0.4 \pm 1.1 \times 10^{3}$ & $7.6 \pm 16.1$ & $2639 \pm 1568$ \\
\hline \multicolumn{5}{|l|}{ Ciliates } \\
\hline Oligotrichs & 16 & $3.8 \pm 7.4 \times 10^{3}$ & $7.8 \pm 11.4^{b}$ & $3343 \pm 2964$ \\
\hline Ciliates (misc.) & 13 & $0.7 \pm 2.2 \times 10^{3}$ & $30.2 \pm 95.8^{b}$ & $3762 \pm 4011$ \\
\hline Holotrichs & 16 & $0.7 \pm 2.2 \times 10^{3}$ & $5.4 \pm 8.7^{b}$ & $6580 \pm 7388$ \\
\hline Euplotes spp. & 10 & $2.5 \pm 2.4 \times 10^{2}$ & $0.5 \pm 0.6^{b}$ & $2250 \pm 2361$ \\
\hline \multicolumn{5}{|l|}{ Metazoans } \\
\hline Copepod nauplii & 5 & $2.7 \pm 2.2 \times 10^{2}$ & $5.2 \pm 4.6$ & $18230 \pm 1073$ \\
\hline \multicolumn{5}{|c|}{$\begin{array}{l}\text { as discussed under 'Methods', samples are from brine or seawater collected from within the ice floes, so cell lysis during } \\
\text { melting is not expected. However, some sample counts were based on counts of preserved, settled samples (i.e. no filters were } \\
\text { prepared for analysis by fluorescence microscopy) and flagellate values may be underestimated in our analysis } \\
{ }^{b} \text { Ciliate biomass calculated at volume } \times 0.08 \text { to remain consistent with Moloney \& Field (1989) allometric equations }\end{array}$} \\
\hline
\end{tabular}


annual (i.e. first-year) sea ice. First-year ice is the predominant ice comprising the pack ice surrounding Antarctica (Foster 1984), and during the months of November to mid-January most of the seasonal sea ice melts (e.g. Gordon 1981, Comiso \& Zwally 1984). Moreover, the winter-to-spring transition is also a time of increasing solar radiation and warmer temperatures (Fig. 2) that should favor production in both ice and plankton. Thus, the overall importance of ice-based production may depend on the rate at which the various ice assemblages develop relative to the rate of destruction of the habitat by seasonal ablation.

During our early-spring study, we measured concentrations of chlorophyll a up to about $54 \mu \mathrm{g} \mathrm{l^{-1 }}$ in the surface-layer assemblages and in the interior assemblages from a multi-year floe (Table 1). Although chlorophyll a concentrations were high in multi-year ice, this type of ice forms only a small proportion of the seasonal sea ice. Moreover, the chlorophyll stocks in these older floes may represent an accumulation of biomass from one or more growth seasons, so that high pigment concentrations are not necessarily an indication of high production rates. Based on a large number of chlorophyll measurements from pack ice (Garrison \& Buck 1989a, Dieckmann et al. 1990), we have argued that the surface-layer assemblages, rather than the more widely distributed internal asemblages, appear to be the most active sites of algal production in pack ice. The production rates and seasonal development of the surface-layer assemblages are the focus of this paper because we believe that these are the beginning of assemblages that are capable of attaining high biomass with chlorophyll concentrations reaching $>400 \mu \mathrm{g} \mathrm{I}^{-1}$ in late summer (e.g. as reported by Meguro 1962, Burkholder \& Mandelli 1965, Kristiansen \& Syvertsen 1990).

Absolute production rates $\left(\mathrm{mgC} \mathrm{m}^{-3} \mathrm{~d}^{-1}\right)$, assimilation ratios ( $\mu \mathrm{gC}[\mu \mathrm{g} \mathrm{Chl} \mathrm{a}]^{-1} \mathrm{l}^{-1} \mathrm{~h}^{-1}$ ) and specific growth rates ( $\mu$ : doublings $\mathrm{d}^{-1}$ ) varied among the samples, with the highest production reaching $>1 \mathrm{gC} \mathrm{m}^{-3} \mathrm{~d}^{-1}$ with a corresponding growth rate of 0.6 doubllings $\mathrm{d}^{-1}$ (Table 2). Similar production rates in surface-layer assemblages have been reported by Burkholder \& Mandelli (1965) during summer, and by Kottmeier \& Sullivan (1990) during autumn. Assimilation ratios fall within the range of values reported by Lizotte \& Sullivan (1991) (e.g. 0.3 to 3.0). Specific growth rates among the samples ranged from 0.2 to 0.6 doublings $\mathrm{d}^{-1}$; maximum growth rates (Fig. 3) are near the maximum rates predicted from Eppley's (1972) temperature relationship and they are in close agreement with growth of Antarctic phytoplankton predicted as a function of temperature and daylength (Tilzer \& Dubinsky 1987).

Experiments with a variable light regime showed no indication of inhibition at full surface light (Fig.3).
Lizotte \& Sullivan (1991) have recently reported that algae from the pack ice show saturation levels $\left(I_{k}\right)$ similar to those of phytoplankton reaching saturation at $>40 \mu \mathrm{E} \mathrm{m}^{-2} \mathrm{~s}^{-1}$, and Burkholder \& Mandelli (1965) reported relatively high assimilation ratios (e.g. 2.6) at $400 \mu \mathrm{E} \mathrm{m}^{-2} \mathrm{~s}^{-1}$. Thus the response that we observed during spring is consistent with other studies and not unexpected. To estimate actual in situ growth conditions, we calculated light levels at the level of the surface assemblage by using an albedo ranging from 0.85 to 0.75 and attenuation coefficients $(k)$ for snow and first-year sea ice ranging from 10 to $15 \mathrm{~m}^{-1}$ and 1.0 to $0.8 \mathrm{~m}^{-1}$ respectively; according to data summarized by Maykut (1985), these values should span the range of near freezing to melting conditions such as those we observed during the study (Fig. 2). These calculations indicate that surface assemblages under $10 \mathrm{~cm}$ of snow would experience ca 5 to $20 \%$ of surface radiation depending on the physical conditions of ice and snow (self absorption by the algae was ignored for this calculation). Our measurements at $30 \%$ light levels may overestimate actual in situ growth rates (i. e. rates of 0.10 doublings $\mathrm{d}^{-1}$ were found at $5 \%$ surface light in our gradient experiments and these may be more typical of average in situ growth rates; Fig. 3).

Light is most often suggested as the important variable controlling algal growth in sea ice (e.g. Horner 1985, Grossi et al. 1987). We found that absolute production rates and assimilation ratios were negatively correlated with snow depth (Table 4). This may indicate a lower photosynthetic capacity of the more shaded populations, but this correlation is based on few data points. However, Lizotte \& Sullivan (1991) reported a similar response for internal algal assemblages found deeper in pack ice floes. With a larger data base, we found no correlation of algal concentrations (i.e. Chl a) with snow depth. Other workers (e. g. Grossi et al. 1987) have shown pronounced negative relationships between both growth rate and chlorophyll a accumulation and snow depth, which have indicated the role of light limitation. There are several reasons why this relationship may not be readily apparent in the pack ice. For example, algae can be mechanically concentrated in ice (Garrison et al. 1983, 1989), so that chlorophyll a concentrations do not necessarily reflect biomass accumulation as the result of in situ growth. This physical incorporation would be most likely to obscure the evidence for any in situ growth at the early stages of seasonal development. Moreover, snow depth may change rapidly as the result of wind drifting (Ackley 1988), so that snow depth may or may not give an accurate indication of previous light history of underlying algal populations. Irwin (1990) has also suggested that in pack ice regions with small dispersed floes, a considerable amount of light may 
Table 4. Correlation analysis of physical, chemical and biological variables in surface-layer sea ice assemblages. Values were transformed by $\log _{10}$ (value) $\left[\right.$ or $\log _{10}($ value +1 ) for variables with values $<1.0$ or 0$]$. Pearson's $(\mathrm{R})$ shown for variable pairs; $(\mathrm{N})$ is given for each variable. $\mathrm{C} / \mathrm{P}=\mathrm{Chl}$ a/Phaeopigments; Prod $=$ production $\mathrm{h}^{-1}$; Snow $=$ snow depth; ice: floe thickness; $\mathrm{Si}=$ silicate; Het $=$ heterotrophic biomass $\left(\mu \mathrm{gC} \mathrm{I}^{-1}\right) ; \%$ Het $=$ heterotrophic biomass (autotrophic + heterotrophic biomass) ${ }^{-1}$. See Tables 1 and 2 for identity and units of other variables

\begin{tabular}{|c|c|c|c|c|c|c|}
\hline & $\begin{array}{l}\text { Chl a } \\
(26)\end{array}$ & $\begin{array}{c}\text { Phaeo } \\
(26)\end{array}$ & $\begin{array}{l}\mathrm{C} / \mathrm{P} \\
(26)\end{array}$ & $\begin{array}{c}\text { Prod } \\
(5)\end{array}$ & $\begin{array}{l}P / C \\
(5)\end{array}$ & $\begin{array}{c}\mu \\
(5)\end{array}$ \\
\hline Snow (21) & 0.26 & 0.23 & -0.36 & $-0.93^{\circ}$ & $-0.90^{\circ}$ & -0.71 \\
\hline Ice (20) & 0.03 & 0.10 & 0.18 & 0.42 & 0.64 & 0.43 \\
\hline Salin (21) & -0.10 & -0.08 & 0.03 & 0.52 & 0.15 & 0.33 \\
\hline $\mathrm{PO}_{4}(15)$ & -0.11 & -0.13 & -0.26 & 0.21 & 0.59 & 0.11 \\
\hline $\mathrm{NO}_{3}(15)$ & -0.01 & -0.3 & 0.11 & -0.01 & 0.41 & -0.19 \\
\hline Si (15) & -0.19 & -0.15 & 0.18 & 0.31 & 0.62 & 0.01 \\
\hline Het (16) & 0.32 & 0.27 & -0.01 & 0.76 & 0.39 & 0.76 \\
\hline$\%$ Het $(16)$ & $-0.53^{\circ}$ & $-0.54^{*}$ & 0.06 & -0.70 & $-0.94^{\circ}$ & -0.54 \\
\hline \multicolumn{7}{|c|}{ - Significant at $p<0.05$} \\
\hline
\end{tabular}

enter ice from the side of floes, so that snow cover may not always be the dominant variable determining the in situ light regime.

The growth rates we estimated would explain the seasonal development of the surface-layer assemblage. For example, sustained growth rates of algae in surface assemblages as low as 0.10 doublings $\mathrm{d}^{-1}$ would be sufficient to account from an increase in chlorophyll concentrations from ca $1.0 \mathrm{\mu g} \mathrm{l}^{-1}$ in early November to $>$ $400 \mu \mathrm{g} \mathrm{Chl} \mathrm{a} \mathrm{l}^{-1}$ in late December/early January (e. g. Meguro 1962, Burkholder \& Mandelli 1965, Kristiansen \& Syvertsen 1990). It should be apparent, however, that such biomass accumulations would require net nutrient transport in to ice floes. Using a Carbon:Nitrogen ratio of ca 7 and Si:Carbon ratio of 0.13 (e.g. Nelson et al. 1987) and assuming that nutrient concentrations in seawater are a conservative estimate of initial nutrient concentrations in sea ice (see Garrison et al. 1990 for a discussion of this assumption), we calculated that biomass accumulation in ice would be limited to ca 1.5 to $2.0 \mathrm{mgC} \mathrm{I}^{-1}$ without the input of additional nutrients. Some of our samples were within this range (Fig. 4a); unfortunately, among the samples showing high biomass, only Sample 209 had corresponding data for nutrients and production. This may explain our failure to see any evidence of nutrient depletion on growth rates and biomass concentrations (Table 4) in spite of some samples showing relatively low nutrient concentrations (Table 1).

\section{Heterotrophic consumption in ice}

Some previous studies (see e.g. review by Horner 1985) have assumed that ice algal assemblages develop free from grazing pressure. These reports may be the result of failing to recognize protozoan consumers in the ice and/or the destruction of these forms by inappropriate sample processing (Garrison \& Buck 1986). Based on the abundance of heterotrophic protozoans in ice (Fig. 4b, Table 3; Garrison et al. 1986, Garrison \& Buck 1989a, Garrison 1991), we have argued that heterotrophs may be a sink for ice-based primary production. The negative correlation of chlorophyll a concentrations with the percentage of heterotrophs comprising the assemblage (Table 4) suggests a grazing effect in our samples. However, there are presently no measurements of consumption rates by heterotrophic protozoans from ice communities. For similar protozoan assemblages in the water column, we have used clearance rates from the literature to calculate probable carbon budgets (Garrison \& Buck 1989c). Using this approach for the ice assemblage, suggests moderately high clearance rates for many of the heterotrophic protozoans at the densities they occur in ice (Fig. 5a). Since many physiological and ecological processes are size-dependent, it should also be possible to estimate ingestion and respiration rates for ice-associated protozoans from the size distributions of populations. We used the allometric equations of Maloney \& Field (1989) to estimate mass specific ingestion and respiration:

$$
\begin{gathered}
I_{\max }\left(\mathrm{d}^{-1}\right)=63 \mathrm{M}(\mathrm{pgC})^{-0.25} \\
R\left(\mathrm{~d}^{-1}\right)=14 \mathrm{M}(\mathrm{pgC})^{-0.25}
\end{gathered}
$$

Where $\mathrm{I}$ and $\mathrm{R}=$ mass specific ingestion and respiration rates, respectively; $M=$ carbon cell $^{-1}$. The slopes of the regressions (i.e. 63 and 14) were reduced from $20^{\circ} \mathrm{C}$ to $-1{ }^{\circ} \mathrm{C}$ assuming a $Q_{10}$ of 2.5 . $Q_{10}$ values of 2 to 3 were used by Moloney \& Field (1989) to scale the original data to $20 \mathrm{C}^{\circ}$ for their analysis, and $\mathrm{Q}_{10}$ values of ca 2.5 for respiration and growth have been reported in a number of studies of Antarctic communities (reviewed in Vincent 1988). A preliminary study by Lee \& Fenchel (1972) indicated that scaling down phy- 


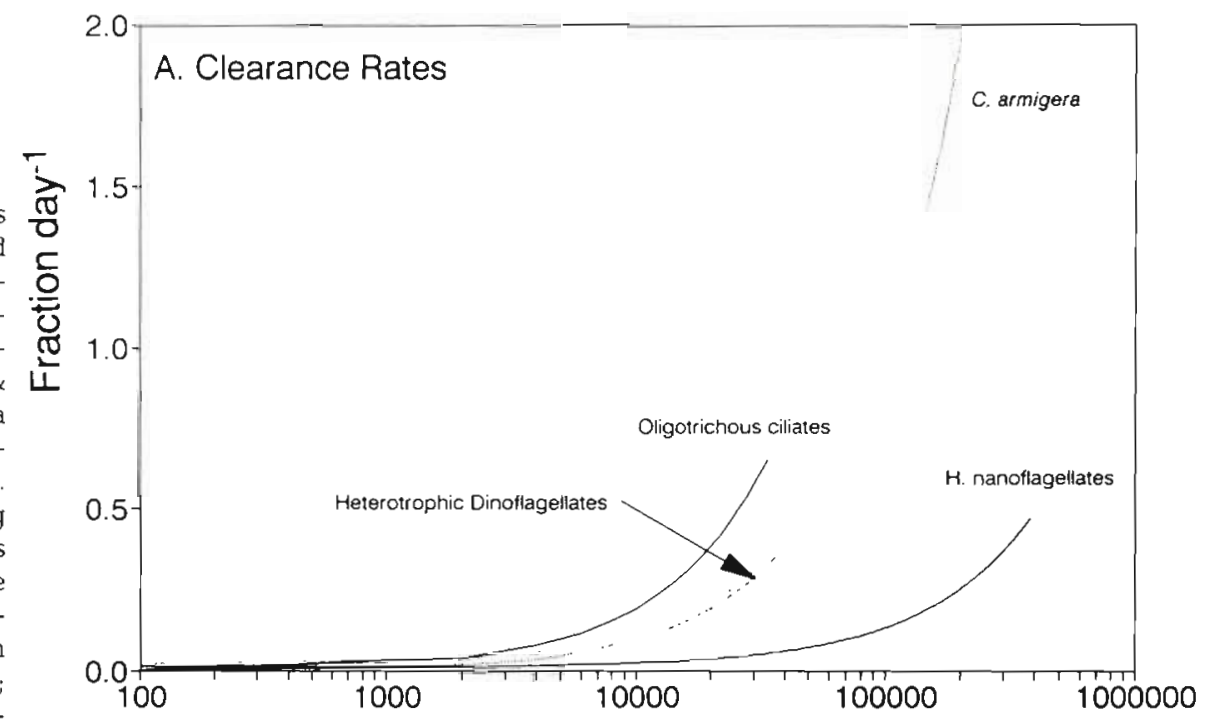

Fig. 5. (A) Population clearance rates for specific groups of organisms found in surface-layer assemblages. Clearance rates for heterotrophic flagellates feeding on bacteria $(0.04 \mu \mathrm{l}$ organism $^{-1} \mathrm{~h}^{-1}$ ) taken from Davis \& Seiburth (1984) for Sargasso Sea flagellates at bacterial densities similar to those reported from sea ice (e. $\mathrm{g}$ Kottmeier \& Sullivan 1990). Using these data for low-latitude flagellates may overestimate flagellate clearance rates because Davis \& Sieburth's volume-specific clearance rates are high among those reported from literature; however, other volume-specific clearance rates seem to be similar over a wide range of environments (Capriulo 1990, E. Lessard Univ., Washington). Clearance rates for antarctic ciliates and heterotrophic dinoflagellates $(0.8$ and $0.4 \mu \mathrm{lorganism}{ }^{-1} \mathrm{~h}^{-1}$ ) were taken from Lessard et al. (1987), Cyrothecomonas armigera is known to feed on autotrophic flagellates and a grazing rate similar to those for heterotrophic dinoflagellates was assumed for this calculation (Thomsen et al. in press). Population clearance rates are calculated for the range of organism densities found in sea ice and expressed as fraction of the water volume cleared per day. (B) Maximum ingestion rates calculated from average cell mass (Table 3 ) over the range of organism densities found in sea ice using allometric equations given by Moloney \& Field (1989). Ciliate carbon was calculated as Volume $\times 0.08$ to remain consistent with Maloney \& Field's (1989) analysis. Respiration rates can be estimated by multiplying $\mathrm{I}_{\max }$ carbon by 0.22

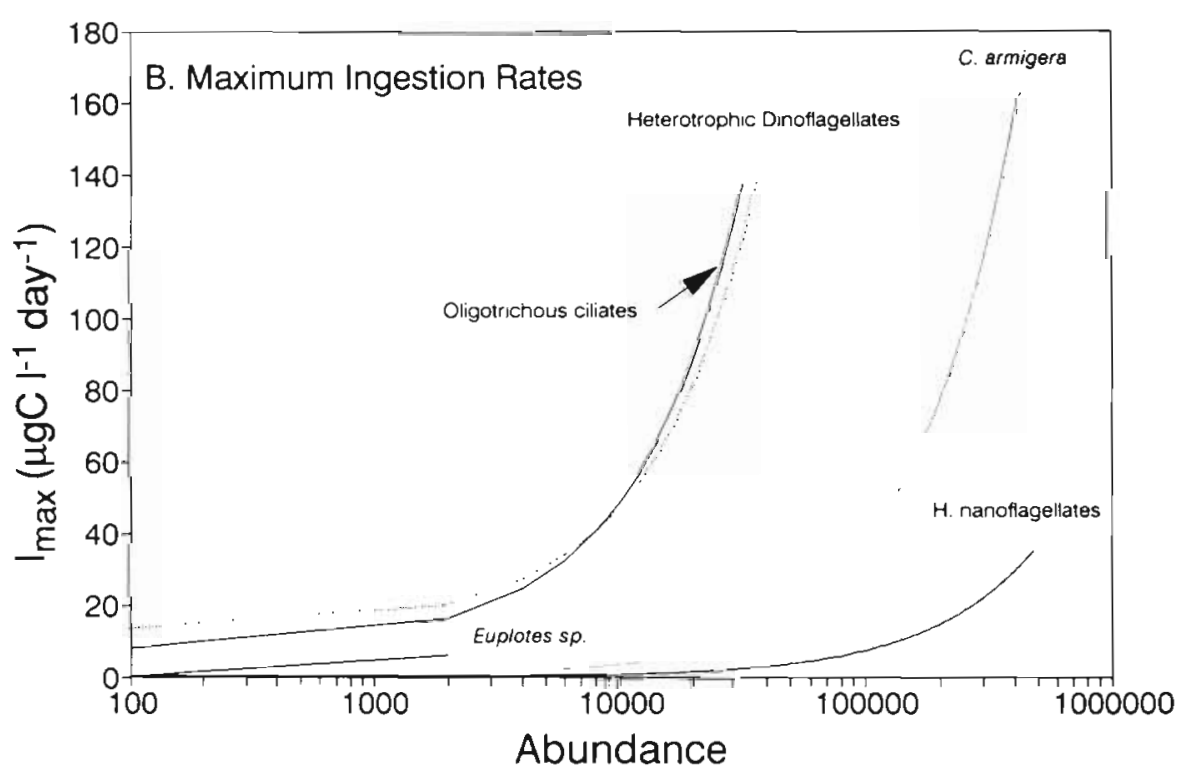

siological rates from temperate species may be appropriate for estimating activity at polar temperatures. The values predicted for maximum ingestion (Fig. 5b) are the same order of magnitude as the carbon production indicated by production experiments (Table 2). Because there is considerably variability in the composition of the heterotrophic biomass among samples (Fig. 5b; see also Garrison \& Buck 1989a) and in the size of the organisms (e.g. Table 3), consumption was calculated for the individual samples (Fig. 6). For all but one of the samples where production was measured, estimate of maximum potential consumption exceeded the measured net production, but in most samples production would have been sufficient to supply respi- ration requirements. The importance of bacterial production is not accounted for in our analysis, because bacterial productivity was not measured in ice during this spring cruise, but under similar conditions in other seasons, bacterial production has been shown to exceed that of the algae (Kottmeier \& Sullivan 1990).

Community grazing measurements are needed to accurately assess heterotrophic carbon utilization within the ice community but results of calculations, such as those in Figs. $5 \& 6$, serve to demonstrate that grazing should be a significant factor controlling the development of and succession within the ice assemblages. For example, the predominance of colonial forms of Phaeocystis in some well-developed surface 


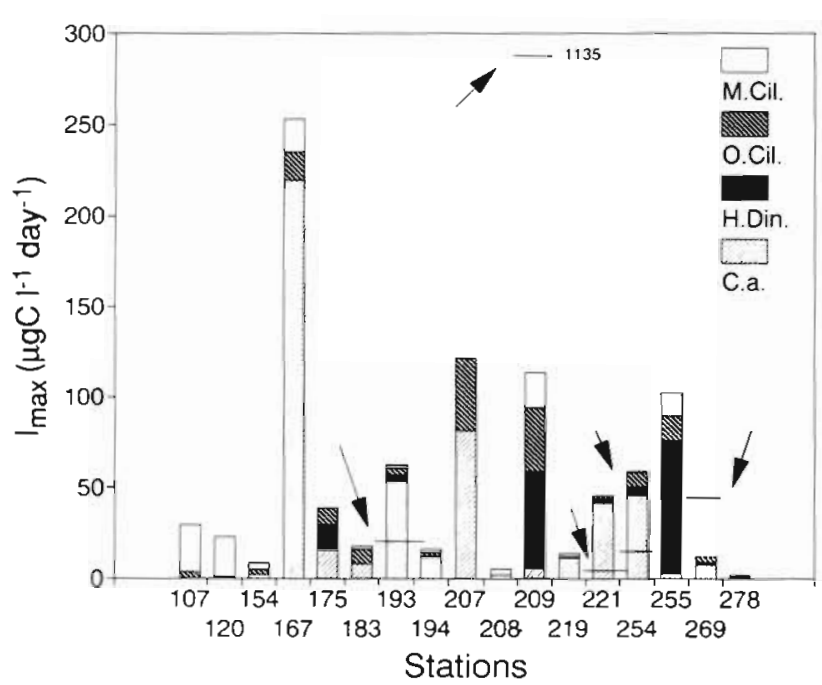

Fig. 6. Maximum carbon utilization by heterotrophic members of the ice assemblages estimated from maximum ingestion rates (Fig. 5 and text). These values calculated using average sizes and abundances for individual samples. Respiration requirements can be calculated as $I_{\max } \times 0.22$. Horizontal bars (with arrows) are daily primary production rates measured on some of these samples (Table 2). Heterotrophic nanoflagellates, which presumably feed on bacteria, are not included in this carbon budget

layer assemblages may be a reflection of their unsuitability for consumers (see Fryxell \& Kendrick 1988 for a pertinent discussion regarding the plankton community). The role of metazoan grazers has been ignored in our analysis. Copepod nauplij in our samples were probably not developed to the feeding stage, but large copepod fecal pellets were found in several samples (Garrison \& Buck 1989a), and larval krill have often been found within floes (Garrison et al. 1986, Daly \& Macaulay 1988, Daly 1990, Garrison 1991), so that grazing by metazoans could be significant at times. Moreover, if there is significant grazing within the ice floes, the ice matrix can become an accumulation site for feces and detritus which will eventually be released with ice melting (e.g. Buck et al. 1989). The patchy distribution of well-developed surface layer assemblages makes it difficult to calculate their contribution to overall ice-based production. The assumption of a $100 \mathrm{~d}$ growth season (e. g. Horner 1985) is conservative. since we have determined that growth starts in these assemblages at least by November, and we also know that they persist in some floes into the autumn (Buck et al. 1989, Garrison \& Buck 1989a). Their overall importance in the late summer-to-autumn period, however, would be diminished because of the seasonal minimum in sea-ice cover during this period (e.g. Gordon 1981). There is less of a basis, however, for predicting their spatial distributions. In this study we have indications that the development of the surface layer assemblages may depend on the interaction of several variables including light, temperature, nutrient and grazers. The seasonal increase in solar radiation and temperature will predictably increase brine volume (biospace occupied by the ice biota) and the transmission of solar radiation for both ice and snow (Maykut 1985). At some critical level of in situ radiation, growth should be initiated providing there is a viable inoculum present. Based on the total nutrients required to account for the biomass at the highest algal concentrations reported nutrient transport from the water column must be a part of the seasonal development process. We have suggested that the initial development of algal populations along the perimeter of some floes may reflect the pathway of nutrient transport into floes, but increased horizontal light flux into floes in areas of open pack ice (e. g. Irwin 1990) cannot be discounted in initiating this process. As Buynitskiy (1968) described earlier, when algal growth is initiated selective absorption of solar radiation will enhance local melting, so the spread of algal assemblages throughout floes, which is apparent from some shipboard observations on some floes, may just be a continuation of the process that we observed on the edge of ice floes.

In the literature surface-layer assemblages are assumed to be associated with flooding and the formation of an infiltration ice layer (e.g. Meguro 1962, Burkholder \& Mandelli 1965, Whitaker 1977, Horner 1985, Horner et al. 1988, Kristiansen \& Syvertsen 1990), and there is ample evidence that infiltration ice is common in the Weddell Sea (Ackley 1988, Lange et al. 1990). The assemblages that we describe, however, were usually within the upper 5 to $30 \mathrm{~cm}$ of hard sea ice in a porous layer near the freeboard level in ice floes and apparently develop from internal assemblages (Ackley et al. 1979). Many pack-ice floes have a shallow freeboard (e.g. Lange et al. 1990) with little physical separation between the snow-ice interface and the porous layer at sea level, so that either infiltration layer or shallow interior populations can develop as surface assemblages (or these assemblages may be confluent). The frequent use of 'infiltration layer' to refer to most surface assemblages suggests to us that shallow internal assemblages are often mistaken for infiltration assemblages. The ecological distinction between these 2 assemblages is relevant to understanding the time course and nature of community development. For example, the inoculum for an interior assemblage is apparently established at the time of ice formation (e. $g$ Garrison et al. 1983), and thus overwinter survival in the ice is an important consideration. In contrast, an infiltration assemblage, which is inoculated when flooding occurs, would be heavily influenced by the composition of the plankton at the time of flooding. The source and condition of an initial inoculum could be as important in determining the predictability of surface- 
layer assemblage development as the other variables that we have discussed in relation to our spring study.

Acknowledgements This study was supported by NSF grants to D. L. Garrison and M. W. Silver (DPP 82-18747), D. L. Garrison (DPP 84-20184, DPP 88-15799). Final work on this manuscript was completed while D. L. Garrison was a Visiting Researcher at the National Institute of Polar Research of Japan, and we gratefully acknowledge this support. We thank D. M. Nelson, L. I. Gordon and W. O. Smith, Jr, for assistance with the production measurements, the use of their light data and for analyzing our ice nutrient samples. A considerable amount of our insights about the physical and chemical features of the ice habitat have evolved as the result of discussion with S. F. Ackley over the years, and we gratefully acknowledge his contribution to our understanding of the biology of the ice community.

\section{LITERATURE CITED}

Ackley, S. F. (1988). Snow cover effects on Antarctic ice thickness. EOS Trans. Am. geophys. Un. 69: 1262

Ackley, S. F., Buck, K. R., Taguchi, S. (1979). Standing crop of algae in the sea ice of the Weddell Sea region. Deep-Sea Res. 26A: 269-281

Ainley, D. G., Sullivan, C. W. (1984). AMERIEZ 1983; a summary of activities on board the R/V Melville and USCGC Westwind. Antarctic J. U.S. 19: 100-103

Atlas, E. L., Hager, S. W. Gordon, L. I. Park, P. K. (1971). A practical manual for use of the Technicon AutoAnalyzer in seawater nutrient analyses. Tech. Rep. 215: 55-67

Beers, J. R., Stewart, G. L. (1970). Numerical abundance and estimated biomass of microzooplankton. In: Strickland, J. D. H. (ed.) The ecology of the plankton off La Jolla, California in the period April through September, 1967. Bull. Scripps Inst. Oceanogr. 17:67-87

Buck, K. R., Bolt, P., Garrison, D. L. (1989). Phagotrophy and fecal pellet production by an athecate dinoflagellate in Antarctic sea ice. Mar. Ecol. Prog. Ser. 60: 75-84

Burkholder, P. R., Mandelli, E. F. (1965). Productivity of microalgae in Antarctic sea ice. Science 148: 872-874

Buynitskiy, V. Kh. (1968). The influence of microalgae on the structure and strength of Antarctic sea ice. Oceanography 8: 771-776

Capriulo, G. M. (1990). Feeding-related ecology of marine Protozoa. In: Capriulo, G. M. (ed.) Ecology of marine Protozoa. Oxford University Press, New York, p. 186-259

Clarke, D. B., Ackley, S. F. (1984). Sea ice structure and biological activity in the Antarctic marginal ice zone. J. geophys. Res. 89: 2087-2095

Comiso, J. C., Sullivan, C. W. (1986). Satellite microwave and in situ observations of the Weddell Sea ice cover and its marginal ice zone. J. geophys. Res 91. 9663-9681

Comiso, C. J., Zwally, H.J. (1984). Concentration gradients and growth/decay characteristics of the seasonal ice cover. J. geophys. Res. 89: 8081-8103

Daly, K. L. (1990). Overwintering development, growth and feeding of larval Euphausia superba in the Antarctic marginal ice zone. Limnol. Oceanogr. 35: 1564-1576

Daly, K. L., Macaulay, M. (1988). Abundance and distribution of krill in the ice edge zone of the Weddell Sea, austral spring 1983. Deep-Sea Res. 35: 21-41

Davis, P. G., Sieburth, J. McN. (1984). Estuarine and ocean microflagellate predation of actively growing bacteria: estimation by frequency of dividing-divided bacteria. Mar Ecol. Prog. Ser 19: 237-246

Dieckmann, G., Sullivan, C. W., Garrison, D. L. (1990). Seasonal standing crop of ice algae in pack ice of the Weddell Sea. EOS Trans. Am. geophys. Un. $71: 79$

Eppley, R. W. (1972). Temperature and phytoplankton growth in the sea. Fish. Bull. U.S. 70: 1063-1085

Eppley, R. W., Reid, F. M. H., Strickland, J. D. R. (1970). Estimates of phytoplankton crop size, growth rate, and primary production. In: Strickland, J. D. R. (ed.) The ecology of the phytoplankton off La Jolla, California in the period April through September, 1967. Bull. Scripps Inst. Oceanogr. 17. 33-42

Foster, T D. (1984). The marine environment. In: Laws, R. M. (ed.) Antarctic ecology, Vol. 2. Academic Press, London, p. 345-371

Fryxell, G. A., Kendrick, G. A. (1988). Austral spring microalgae across the Weddell Sea ice edge: spatial relationships found along a northward transect during AMERIEZ 83 Deep-Sea Res. 35: 1-20

Garrison, D. L. (1991). Antarctic sea ice biota. Am Zool. 31 $17-33$

Garrison, D. L., Ackley, S. F., Buck, K. R. (1983). A physical mechanism for establishing algal populations in frazil ice. Nature, Lond., 306: 363-365

Garrison, D. L., Buck, K. R. (1986). Organism losses during ice melting: a serious bias in sea ice community studies. Polar Biol. 6: 237-239

Garrison, D. L., Buck, K. R. (1989a). The biota of Antarctic pack ice in the Weddell Sea and Antarctic peninsula regions. Polar Biol. 10: 211-219

Garrison, D. L., Buck, K. R. (1989b). Pack ice microbial assemblages during the austral winter (abstract). Twelfth Symposium on Polar Biology, 5-8 December, 1989. National Institute for Polar Research, Tokyo, Japan, p. 65

Garrison, D. L., Buck, K. R. (1989c). Protozooplankton in the Weddell Sea, Antarctica: abundance and distributions in the Ice-edge zone. Polar Biol. 9: 341-351.

Garrison, D. L., Close, A. R., Gordon, L. I. (1990). Nutrient concentrations in Antarctic pack ice during the austral winter. In: Ackley, S. F., Weeks, W. F. (eds.) Sea ice properties and processes. Proceedings of W. F. Weeks Sea Ice Symposium, CRREL, Monograph 90-1, p. 35-40

Garrison, D. L., Close, A. R., Reimntz, E. (1989). Algae concentrated by frazil ice: evidence from laboratory and field measurements. Antarctic Sci. 1: 313-316

Garrison, D. L., Sullivan, C. W., Ackley, S. F. (1986). Sea ice microbial communities in Antarctica. BioScience 36: $243-250$

Gold, K. (1976). Methods for preserving Tintinnida. In: H. F. Steedman (ed.) Zooplankton fixation and preservation. UNESCO, Paris, p. 236-239

Gordon, A. L. (1981). Seasonality of southern ocean sea ice. J. geophys. Res. 86: 4193-4197

Grossi, S. M., Kottmeier, S. T., Moe, R. L., Taylor, G. T., Sullivan, C.W. (1987). Sea ice microbial communities. VI. Growth and primary productivity in bottom ice under graded snow cover. Mar. Ecol. Prog. Ser. 35: 153-164

Horner, R. (1985). Ecology of sea ice microalgae. In: Horner, R. (ed.) Sea ice biota. CRC Press, Boca Raton, Florida, p. 83-103

Horner, R. A., Syvertsen, E. E., Thomas, D. P., Lange, C. (1988). Proposed terminology and reporting units for sea ice algal assemblages. Polar Biol. 8: 249-253

Hoshiai, T. (1981). Proliferation of ice algae in the Syowa station area, Antarctica. Mem. natn. Inst. polar Res. (Series E, Biology) 34: 1-12 
Irwin, B. D. (1990). Primary production of ice algae on a seasonally-ice covered, continental shelf. Polar Biol 10: $247-254$

Kottmeier, S. T., Sullivan, C.W. (1987). Late winter primary production and bacterial production in sea ice and seawater west of the Antarctic Peninsula. Mar. Ecol. Prog. Ser. 36: $227-298$

Kottmeier, S. T., Sullivan, C. W (1990). Bacterial biomass and production in pack ice of Antarctic marginal ice edge zones. Deep-Sea Res. 37: 1311-1330

Kristiansen, S., Syvertsen, E. E. (1990). Sea ice algae in the Weddell Sea during austral spring. EOS Trans. Am. geophys. Un. $71: 79$

Lange, M. A., Schlosser, P., Ackley, S. F., Wadhams, P., Dieckmann, G. S. (1990). ${ }^{18} \mathrm{O}$. Concentrations in sea ice of the Weddell Sea, Antarctica. J. Glaciol. 36: 315-323

Lee, C. C., Fenchel, T (1972). Studies on ciliates associated with sea-ice from Antarctica: II. Temperature responses and tolerances in ciliates from Antarctica, temperate and tropical latitudes. Arch. Prostistenk. 114: 237-244

Lessard, E. J., Voytek, M. A., Rivkin, R. B. (1987). The heterotrophic-based nutrition of the microzooplankton and macrozooplankton of McMurdo Sound, Antarctica. EOS Trans. Am. geophys. Un. 68: 1773

Lizotte, M. P., Sullivan, C.W. (1991). Photosynthesisirradiance relationships in microalgae associated with Antarctic pack ice: evidence for in situ activity. Mar. Ecol. Prog. Ser. 71: 175-184

Maykut, G. A. (1985). The ice environment. In: Horner, R. (ed.) Sea ice biota. CRC Press, Boca Raton, Florida, p. 21-82

Meguro, H. (1962). Plankton ice in the Antarctic Ocean. Antarctic Rec. 14: 1192-1199

Moloney, C. L., Field, J. G. (1989). General allometric equations for rates of nutrient uptake, ingestion, and respiration in planktonic organisms. Limnol. Oceanogr. 34: 1290-1299

Nelson, D. M., Smith, W. O., Gordon, L. I., Huber, B. A. (1987).

This article was submitted to editor
Spring distribution of density, nutrients and phytoplankton biomass in the ice-edge zone of the Weddell/Scotia Sea. J. geophys. Res. 92: 7181-7190

Palmisano, A. C., Sullivan, C.W. (1983). Sea ice microbial communities (SIMCO). I: Distribution, abundance, and primary productivity of ice microalgae in McMurdo Sound, Antarctic in 1980. Polar Biol. 2: 171-177

Parsons, T.R., Maita, Y., Lalli, C. M. (1984). A manual of chemical and biological methods for seawater analysis. Pergamon Press, Oxford

Putt, M., Stoecker, D. K. (1989). An experimentally determined carbon:volume ration for marine 'oligotrichous' ciliates from estuaries and coastal waters. Limnol. Oceanogr. 34: 1097-1103

Reid, F. M. H. (1983). Biomass estimation of components of marine nanoplankton and picoplankton by the Utermöhl method. J. Plankton Res. 5: 235-251

Smith, W. O., JT, Nelson, D. M. (1990). Phytoplankton growth and new production in the Weddell Sea marginal ice-zone during austral spring and autumn: a comparison. Limnol. Oceanogr. 35: 809-821

Thomsen, H. A., Buck, K. R., Bolt, P. A., Garrison, D. L. (in press). Fine structure and autecology of Cryothecomonas gen. nov. (Protista incerta sedis) from the ice biota. Can. J. Zool.

Tilzer, M. M., Dubinsky, Z. (1987). Effects of temperature and day length on the mass balance of Antarctic phytoplankton. Polar Biol. 7 : 35-42

Vincent, W. F. (1988). Microbial ecosystems of Antarctica Cambridge University Press, New York

Watanabe, K., Satoh, H. (1987). Seasonal variations of ice algal standing crop near Syowa Station. Jap. J. Phycol. 34: $143-164$

Whitaker, T. M. (1977). Sea ice habitats of Signy Island (South Orkneys) and their primary productivity. In: Llano, G. A. (ed.) Adaptations within Antarctic ecosystems. Gulf Publishing Co., Houston, p. 75-822

Manuscript first received: December 11, 1990

Revised version accepted: June 4, 1991 